ORIGINAL ARTICLE

\title{
Criminal thinking styles of minors. Social and personality correlates
}

\author{
Magdalena Rode \\ Institute of Psychology, Faculty of Pedagogy and Psychology, University of Silesia in Katowice, Katowice, Poland
}

\section{BACKGROUND}

This paper presents an attempt to determine the predictors of criminal thinking styles of minors, based on the theory of Glenn Walters. The construct which is the subject of this study, that is, criminal thinking, is treated as a factor that initiates and supports anti-social behaviour. It manifests itself in eight thinking styles (patterns): mollification, cutoff, entitlement, sentimentality, power orientation, cognitive indolence, discontinuity, and superoptimism.

\section{PARTICIPANTS AND PROCEDURE}

The study involved 114 people: 65 boys and 49 girls. The research group consisted of minors - boys and girls who were referred, by order of the court, to Diagnostic and Consultation Family Centres to receive a psychological opinion, the purpose of which was to determine the degree of demoralisation of the minor. The study was also attended by the guardians of minors. A criterion for including a minor in this study was committing an offence.

\section{RESULTS}

For each criminal thinking style, a forward stepwise regression analysis was conducted. Variables describing mi- nors and mothers were included in the regression model. The aim of this approach is to identify the configuration of predictors of criminal thinking styles. In each of the models the coefficient of determination, $R^{2}$, and $\beta$ coefficients were calculated.

\section{CONCLUSIONS}

The predictors of criminal thinking styles identified by the regression analysis show the complexity and heterogeneity of factors contributing to the emergence of these cognitive distortions. Predictors include both properties conditioning the psychosocial functioning of mothers and factors determining the personality of a minor (sense of control, low empathy, low self-esteem). There is a noticeable influence of factors attributable to the mothers - variables derived from the environment (demanding, rejecting, inconsistent attitude).

\section{KEY WORDS}

juvenile delinquency; family; cognitive distortion; risk factor

Corresponding Author - Magdalena Rode, Ph.D., Institute of Psychology, Faculty of Pedagogy and Psychology,

University of Silesia in Katowice, 53 Grażyńskiego Str., 40-126 Katowice, Poland, e-mail: magdalena.rode@us.edu.pl aUthors' CONTRIBUtion - A: Study design - B: Data collection · C: Statistical analysis · D: Data interpretation . E: Manuscript preparation · F: Literature search · G: Funds collection TO CITE THIS ARTICLE - Rode, M. (2014). Criminal thinking styles of minors. Social and personality correlates.

Current Issues in Personality Psychology, 2(4). RECEIVED 17.09.2014 · REVIEWED 19.09.2014 · ACCEPTED 20.11.2014 · PUBLISHED 02.12.2014 


\section{BACKGROUND}

The precursors of research in cognitive schemas, which determine criminal behaviour, were Yochelson and Samenow $(1976,1977)$. They identified 52 errors of thinking, which they believed would characterise thinking of the criminal personality. According to their assumptions, the sources of delinquency should be seen in the way of thinking of an individual and the method of decision-making. Another researcher of patterns of thought is G. D. Walters, who, in his monograph titled The Criminal Lifestyle. Patterns of Serious Criminal Conduct (1990) concerning the criminal lifestyle, presented the thesis of the criminal thinking style. The author assumes that criminal behaviour is determined by three groups of factors: external (environmental) conditions, decision-making processes and a criminal mindset. The belief that criminal thinking is crucial to the criminal behaviour is confirmed by the results of numerous meta-analyses. Of the six variables undergoing the analyses by Gendreau (1992, as in: Walters, 2006a), antisocial attitudes emerged as the strongest predictor of criminal behaviour of adults. This variable dominated over temperamental, personality, and family factors. Similar results were obtained in studies based on a meta-analysis of the main predictors of juvenile delinquency and adults' recidivism. The results of the above-mentioned meta-analyses indicated that criminal thinking is an important area of research in the judicial and penitentiary psychology.

In line with the assumptions of Walters (1989, 1990, 2002, 2006a, 2006b, 2006c), the criminal thinking style is a predictor of the criminal behaviour, and the offence is a moderator of criminal thinking. It justifies and rationalises the behaviour, and fulfils defensive functions in relation to the "self". A criminal thinking style is defined as a "content, matter of thought and a process leading to the initiation and maintenance of behaviour characterised by the habitual violation of the law" (Walters, 2006a, 2006b). By defining this construct, the author draws attention to two aspects. Firstly, it defines the content of thought (thinking), that is to say the specific matter of thought. The second aspect emphasises the processual dimension of thinking that leads to the initiation and ongoing maintenance of behaviour characterised by habitual violation of the law.

The concept of criminal thinking styles by Walters is based on three theories: the differential association theory of E. H. Sutherland, the neutralization theory of G. M. Sykes and D. Matza, and the concept of criminal personality of Yochelson and Samenow. The author of the differential association theory - Sutherland - stated that criminal behaviour is a learned behaviour, through contact with people already involved in crime. He also highlighted the learned nature of offence techniques, themes sup- porting crime: rationalisation and attitudes (Sutherland \& Cressey, 1978, as in: Walters 1990, 2006a, 2006b). This theory assumes that the passive image of a reactive or passive man, who does not choose a specific behaviour, following, e.g., his own needs, will be "pushed" towards criminal behaviour by elements of anti-law culture prevailing in it (cf. Błachut, Gaberle, \& Krajewski, 2006; Siemaszko, 1993). Another model shaping the concept of Walters is the neutralisation theory, which was proposed by Sykes and Matza. It is based also on the mechanism of learning criminal behaviour. The authors of the theory assume that the vast majority of people violating the law see themselves as conventional individuals, rather than as anti-social people. Another assumption is that people apply arguments to justify and rationalise criminal behaviour. They believe that the youth committing crimes internalizes, by the process of socialisation, the correct system of values and norms, but finds ways to justify the failure to follow this system. To explain this process, Sykes and Matza proposed five techniques of neutralisation: denial of responsibility - "it was an accident", denial of harm "no one was hurt", denial of the victim - "the victim asked for it", condemning the damned - "the public is the real culprit", and appealing to higher authorities - "I couldn't disappoint my buddy" (Walters, 2006a). The theory of Sykes and Matza is a presentation of a psychosocial process that facilitates the commission of a crime. The third precursor of the concept of criminal thinking style of Walters is the criminal personality theory of S. Yochelson and S. Samenow (1976). The authors came to a conclusion similar to the theory of moral development and personality disorders. Nevertheless, their point of view of causes of criminal behaviour is based on the idea of free (own) will of an individual. The criminal behaviour is the result of a decision of an individual (Holman \& Quinn, 1992). Yochelson and Samenow identified 52 thinking errors, which they believe characterise criminal personality's thinking.

The criminal thinking styles by Walters determine one's perceptions of himself or herself, the environment and social relationships with the environment. Thinking patterns classified by him are, for an individual, a justification and promotion of personal irresponsibility, indulging, intrusion and breaking social rules (cf. Walters, 1989, 1995a, 1995b, 1996, 1998, 2006a, 2006b, 2006c, 2007). The criminal thinking styles indicate a distortion (and are a manifestation of) human cognitive functioning in terms of an underdevelopment of cognitive structures. These distortions relate to: 1 ) rigidity constituting the inability to reorganise the cognitive structure in terms of new information, 2) rigidity constituting a lack of openness to the flow of information - a cognitive schematism in the detection and evaluation process, 3) a low degree of complexity, or 4) poor information con- 
tent, 5) dysfunction of hierarchical level under the influence of emotional arousal, poor prioritisation of cognitive structures in terms of logic and functionality, 6) a narrow range of cognitive representation of the environment and a low degree of structuring, 7) volatility of the cognitive representation of one's "self" and the outside world, 8) lack of creating relevant information processing and action mobilising strategies (cf. Jakubik, 1997; Obuchowski, 1970; Stanik, 1980). Glenn Walters (2006b) distinguished the following cognitive distortions, which characterise people undertaking criminal activities: 1) mollification - justification of one's own responsibility, involving the attempts to transfer the blame for actions to a variety of external sources (e.g., difficult childhood, bad origin, poverty); 2) cut-off - isolation from responsibility, distancing oneself from the threat of pain, which can result in a punishment for the offence; 3) entitlement - the idea of being a unique person, having a right to ownership and use of the pleasure in life; 4) power orientation - orientation to one's own power; associated with a tendency to control the environment of the individual; 5) sentimentality - emotional infantilism; it is to create the appearance of innocence and integrity of the individual. It is also expressed in attempts to present oneself in the most positive light; 6) superoptimism - an inadequate assessment of one's own abilities, overconfidence, overestimation of one's abilities; 7) cognitive indolence - passivity, cognitive helplessness; 8) discontinuity - a tendency to breach obligations, tasks. For the purposes of this article it has been assumed that the criminal thinking style - manifesting itself in eight cognitive patterns and reflecting the course and essence of the thought process of people carrying out crimes - was formed due to the conditions inherent to the physical, social and psychological area of an individual. This integration and interactive research perspective focuses on the interactions and interrelationships of an individual with the external and internal environment. The process of creating a cognitive representation of reality, encoded in cognitive templates and scripts, occurs in a period of socialisation of an individual. The most expansive moment of the formation of these templates is within the period of childhood and adolescence. The child in this period is the most focused on guardians and, according to his or her development, on other members of society, for example peers. Evolution of cognitive structures is done in many ways, inter alia: through intergenerational transmission, biological properties (temperament, nervous system, etc.), psychological properties, by imitating the behaviour of a parent and through operant and classical conditioning (Huesmann, 2005). Analysis of the literature of risk factors of problem behaviour of children and young people (including criminal behaviour) facilitated the author to select variables that would be used to specify the criminal thinking risk factors model. There were selected those variables that had already adopted the research status of risk factors for the occurrence of abnormal behaviour.

Given the underlying objective of this article specifying predictors of criminal thinking styles of minors - there should be determined all the components participating in the creation and shaping of the cognitive system of an individual - and consequently of the criminal thinking styles. A few studies indicate that there are factors that increase the risk of activation of a particular way of thinking, permanently linked to psychosocial functioning of their parents, their parental attitudes, value system, and risk factors associated with personality traits of juveniles: self-esteem, sense of control, empathy (McClun \& Merrell, 1998; Maruna \& Mann, 2006; Vermeiren, Bogaerts, Ruchkin, Deboutte, \& Schwab-Stone, 2004).

The development of thinking styles is influenced by many different factors, but I will focus on the theoretical assumptions and research of Glenn Walters and his colleagues (Walters, 1990, 2002, 2006c). Hence, the thesis is restricted to the analysis of potential influences of the parental environment as the closest circle of impact and distinguished personality variables of an individual. On the basis of literature data concerning the genesis of the formation of the human cognitive system, it is believed that the environment plays an important role in this process. Within the family functioning, there were taken into account a wide variety of traits, but most of all: anti-social behaviour of members of the family, values, parental attitudes and emotional and behavioural manifestations (e.g., negligence, strict discipline), as well as difficult situations such as divorce and absence of one or two parents (Appleyard, Egeland, van Dulmen, \& Sroufe, 2005; Capaldi, Pears, Kerr, \& Owen, 2003; Gorman-Smith \& Tolan, 1998). For example, McCord (1980, as in: Gorman-Smith \& Tolan, 1998) noted a relationship between parental conflicts and aggressiveness of the parents, and the emergence of criminal behaviour of a violent nature. The second request of the researcher concerned the relationship between lack of maternal care in the context of her emotional unavailability and committing crimes of seizure of property. These relationships were evaluated in longitudinal and transverse research. Loeber and Stouthamer-Loeber (1986; as in: Gorman-Smith \& Tolan, 1998) performed a meta-analysis of empirical data from the longitudinal research devoted to the links between family factors and the criminal behaviour. They identified four heuristic categories of problems implying the emergence and maintenance of juvenile criminal behaviour. These include: 1) negligence - understood in the category of lack of commitment, attention for the child, as well as weak supervision from the parents; 2) conflict - between parents and child, and having the form of re- 
jection of the child by the parent or parents, lack of support and poor emotional relationship; 3) deviant behaviour, attitudes and values; and 4) difficult situations (e.g. distortions). Another factor contributing to the emergence of juvenile criminal behaviour is the system of attitudes and values of parents and their deviant behaviour. The most negative impact on the psychosocial development of an individual is caused by an abnormal emotional relationship between the parent and child, seen in parental attitudes (Borecka-Biernat, 2005). The asocial and antisocial behaviour of a child is treated as a consequence of negative parental attitudes, which take the form of excessive emotional detachment, lack of tolerance, and indifference to the child, severe punishment, excessive requirements or an excessive protective attitude (Barber, Olsen, \& Shagel, 1994; Borecka-Biernat, 2005). In the context of these conditions, there occurs intergenerational transmission of antisocial patterns through learning or acquiring the characteristics of their parents' belief system (Gorman-Smith, Tolan, Loeber, \& Henry, 1998; Farrington, 1994; Farrington, Coid, \& Murray, 2009). This category of problems is a typical antecedent for a group of "chronic juvenile" offenders (serious chronic offenders).

In this article, I evaluate the relationship between criminal thinking styles and selected personality traits of minors and psychosocial functioning of mothers of minors. The results will indicate which of the variables (and in what percentage) are predictors of activation of a criminal thinking style.

\section{PARTICIPANTS AND PROCEDURE}

\section{PARTICIPANTS}

The research involved a group of 1) underage girls and boys who were, under the decision of the Family Court, directed for a psycho-pedagogical test to the Family Diagnostic and Consultation Centre (Rodzinny Ośrodek Diagnostyczno-Konsultacyjny - RODK), and 2) guardians of minors, directed to the RODK for a psycho-pedagogical test. The group of minors consisted of 114 people, including 49 girls and 65 boys. A surprising phenomenon was that in 114 cases the only guardian who attended the study was the mother.

The age range of the minors varied from 12 to 17 years. The average age of the juvenile boys was $M=14.87$, while for the girls it was $M=15.35$. The dominant criminal acts in the group of girls is theft (38.77\%), strike or violation of bodily integrity (24.49\%), use of violence against a person or an unlawful threat to compel another person to a particular activity $(24.45 \%)$, participation in a fight or battery (28.57\%), and robbery $(24.49 \%)$. The boys frequently commit crimes such as robbery $(72.31 \%)$, theft $(58.46 \%)$ and participation in violence and battery (49.23\%).

\section{PROCEDURE}

The research group consisted of minors - boys and girls, as well as their guardians, who were referred, by order of the Court, to a Diagnostic and Consultation Family Centre (RODK) to receive a psychological opinion, whose purpose was to determine the degree of demoralisation of the minor and determine a parental care measure. The ongoing case against the minor was a criminal case. A criterion for including a minor in this study was committing an offence. In accordance with the Act on Juvenile Justice, during the psycho-pedagogical test in an RODK, the minor is under the care of a parent or legal guardian. The places of research were Diagnostic and Consultation Family Centres.

Through an analysis of court records, according to strictly defined criteria, I was able to obtain information covering the general characteristics of selected people, the demographics of minors and their guardians, data on the type and number of criminal offences, the school situation of juveniles, adjudicated parental care and correctional means, as well as information about their environment of origin. Then, juveniles and guardians were interviewed, each separately, which complemented the data obtained from the court records. The next step was to conduct psychological tests with prepared measuring tools on a group of minors and their guardians. The test pool for the minor included: the Thinking Styles Inventory (Inwentarz Stylów Myślenia - PICTS) in Polish, the Tennessee Self Concept Scale by Fitts, the Emotional Reactivity Index by Davis, and the Questionnaire for the Sense of Control Research (Kwestionariusz do Badania Poczucia Kontroli) by Krasowicz and Kurzyp-Wojnarska. The mothers filled in the following tools: PICTS, the Parental Attitude Scale by Plopa, and the Value Survey by Rokeach. The subjects were informed about how to complete these tools and the anonymity of research. Each person could withdraw from participation in the research. The total time to complete the test by the minors was approx. 1 hour, while for mothers it was approx. 35-40 minutes. The resulting material was checked for completeness of fulfilment. As a result, 3 sets were rejected. The last step of the research organisation was a statistical analysis.

\section{MEASURES}

For the purposes of this research, the following research tools were used:

Structured interview with the minor: included demographic data, data on diseases, psychoactive substances, information on socialisation (family structure, educational problems, criminality, course of education). 
Structured interview with the mother: included demographic data of parents, information on diseases, use of psychoactive substances, information on the manner of exercising the parental authority.

Psychological Inventory of Criminal Thinking Styles by Walters. This tool is used to measure eight criminal thinking styles: mollification, cut-off, entitlement, power orientation, sentimentality, superoptimism, cognitive indolence, discontinuity. The present author undertook the adaptation of the tools. The PICTS was subjected to a cultural and semantic adaptation, with particular emphasis on phraseology aspects. The adaptation included an analysis of the theoretical construct, the process of translating and checking the accuracy of the translation, as well as checking the accuracy and reliability of the final version of the test. In this work, an equivalent (universalistic) perspective was adopted. A detailed procedure for the various stages of the test adaptation was described in publications of the author (Rode \& Rode, 2011; Rode, 2013).

Tennessee Self Concept Scale by Fitts. This method is designed to measure a number of aspects of the self-concept (Steuden, 1997). The scale consists of 100 descriptive statements with which the subjects present their own image. The end result in the scale is the global level of self-esteem (PG). It consists of three components: the level reflecting a sense of identity (W1), the level of self-acceptance (W2), and the level of self-assessment of one's own behaviour (W3).

Interpersonal Reactivity Index (IRI) by Davis. This tool determines the level of selected components of empathy. It includes four seven-element subscales involving separate aspects of empathy. This tool consists of: $P T$ scale - perspective-taking - measures the tendency to spontaneously adopt a psychological point of view of others in everyday life; $E C$ scale - empathic concern - assesses the tendency to empathise and feel compassion for people affected by failure; $P D$ scale - personal distress - refers to the tendency to feel pain and discomfort in response to extremely strong suffering of others; $S F$ scale - of fantasy - measures the tendency to, using the imagination, enter fictitious situations (Davis, 1999).

Questionnaire for the Sense of Control Research (Kwestionariusz do Badania Poczucia Kontroli - KBPK) by Krasowicz and Kurzyp-Wojnarska. It is used to measure the personality variable, called a subjective sense of control over one's own behaviour, described in the social learning theory of Rotter (1966, as in: Krasowicz \& Kurzyp-Wojnarska, 1990). The questionnaire consists of 46 questions (36 diagnostic and 10 buffer) forming two scales: $\mathbf{S}$ - of successes (18 questions) and $\mathbf{L}$ - of losses (18 questions). Using the KBPK it is also possible to measure the generalised LOC - without distinction in the sense of control in situations of failures and successes - which is an algebraic sum of the results of both scales $(\mathbf{S}+\mathbf{L})$, correlated with each other and measuring variations of the same variable (the score indicates a generalised trend in attributing responsibility)

Value Scale by Rokeach - developed by Brzozowski $(1989,1996)$. It is used to analyse the system of values. It consists of two scales: the scale of final values (individual and social values) and instrumental values (moral and competence values). The list of final and instrumental values consists of 18 values for each category of values. Both lists are in alphabetical order. The reliability of VS is very high; it is 0.98 (for the final values) and 0.94 (for the instrumental values).

Parental Attitude Scale (PAS-M, PAS-O) by Plopa (2008). This tool is designed to diagnose educational attitudes of parents. It distinguishes 6 types of parental interactions (attitude of acceptance, rejection, autonomy, excessive demanding, inconsistency, and excessive protecting). Each scale consists of 10 statements that showed the highest rates of discrimination power. The reliability of the scales is as follows: The attitude of acceptance-rejection: 0.84 , attitude of autonomy: 0.75 , protective attitude: 0.81 , demanding attitude: 0.88 , inconsistent attitude: 0.88 . The Parental Attitude Scale contains a total of 50 items (10 for each attitude). The examined person takes a stance on the individual statements by selecting one of the five response categories.

\section{RESULTS AND DISCUSSION}

To determine the predictors of risk of criminal thinking styles of minors, logistic regression was used. In order to reduce the number of variables relevant to the dependent variable (the criminal thinking styles), the regression analysis was performed by the forward stepwise method. In each of the models the coefficient of determination, $R^{2}$, and $\beta$ coefficients were calculated (Ferguson \& Takane, 2003).

\section{MOLLIFICATION}

The analysis of regression (Table 1) allowed four predictors of mollification to be indicated.

They explain $69 \%$ of the variance of mollification. The value of the coefficient of determination for the match of the model ranges from $41 \%$ to $69 \%$. The results of the research showed that the biggest impact on the appearance of this cognitive distortion is brought by the mother adopting a protective attitude $(\beta=0.43)$. A very important factor influencing the child's adaptation to the social environment is the nature of the relations between the child and his or her parents. It can be concluded that mollification 
Table 1

Mollification Risk Factors Model

\begin{tabular}{|c|c|c|c|c|c|c|}
\hline Step & Predictor & $R$ & $R^{2}$ & Adjusted $R^{2}$ & Standardised $\beta$ & $p$ \\
\hline 1 & Protective attitude & .54 & .41 & .39 & 0.43 & .004 \\
\hline 2 & Criminal thinking style - mollification mother & .62 & .52 & .49 & 0.30 & .009 \\
\hline 3 & Self-esteem - social "self" & .68 & .55 & .51 & 0.32 & .012 \\
\hline 4 & Global sense of control & .77 & .70 & .56 & 0.38 & .023 \\
\hline
\end{tabular}

thinking is enhanced by over-protective mothers. A permanent cognitive-emotional-behavioural organisation of the mother based on excessive concentration on the child causes limitation of his or her freedom and autonomy. Such an attitude does not develop individuality of the child. By this channel, the child develops a sense of irresponsibility and failure to respond to the consequences of his or her behaviour due to the activity of the mother, showing her belief that the child is helpless and defenceless (cf. Hart, De Wolf, Wozniak, \& Burts, 1992; Hart, Olsen, Robinson, \& Mandleco, 1997). A large number of enhancements from the parent and highlighting its uniqueness in relation to the environment develops in an individual a sense of uniqueness and, consequently, uncriticism. On the other hand, limiting the development of a sense of "self" (identity), by emphasising the role and position of a perceptor, results in a low degree of self-regulation. The consequence of the impact of such a parental attitude is the development of a sense of depending on the model.

On the other hand, the tendency to generate many excuses can arise from a sense of lack of confidence in one's own competence (cf. Midgley, Arunkumar, \& Urdan, 1996; Aunola, Stattin, \& Nurmi, 2000). This assumption seems to confirm the role of self-esteem in the appearance of mollification. Another predictor is one of the indicators of self-esteem: the social "self", which determines the way in which an individual defines the relationship with the social environment and the "value of himself or herself as a participant in interaction with other people" (Fitts, 1975, p. 2). The treatment of self-esteem, and specifically the social "self" as a risk factor of mollification, can be explained by referring to the affective regulation mechanism (cf. Roese \& Olson, 2007). Laying the blame for one's own behaviour on others or external circumstances is associated with a tendency to see oneself in a better light in comparison with others. This allows the individual to maintain a positive affect. In an emergency situation, a negative affect appears. The induced emotional state employs strategies which enhance self-esteem in order to regulate the affective state to a positive level.

The last predictor of mollification is the sense of locus of control. This means that individuals recognise victimological situations as independent from their actions and do not take any responsibility for them. They explain their criminal behaviour by external circumstances. A sense of control is determined by the elements of self-image and elements of the image of the world, as well as what the relationships of "self-world" and "world-self" are. Thus, mollification as a cognitive distortion is a specific kind of dynamic script describing the interactions between people (Baldwin, 1992). This style indicates a trend of self-defence of an individual in the form of blaming others for their actions in order to defend their own "self". The sense of control as a property of a personality moderates the mode of perception of a situation and influences the type of attribution (Dodge, 1991; Dodge \& Tomlin, 1987; Dodge \& Somberg 1987; Dodge \& Coie, 1987; Dodge, Price, Bachorowski, \& Newman, 1990).

\section{SENTIMENTALITY}

The forward stepwise regression analysis allowed, in the first step, the number of variables to be reduced to one, namely the rejecting parental attitude. The details of the regression analysis are presented in Table 2.

Sentimentality is a way of thinking and, consequently, of action, that provides positive feedback about oneself. Behaviour of a person, in particular the reasons for his or her action, can be seen as positive, but this is only a cover for the criminal behaviour. It pretends innocence and honesty. It is expressed in attempts to present oneself in the most positive light and to reduce a negative assessment of an offending

Table 2

Sentimentality Risk Factors Model

\begin{tabular}{ccccccc}
\hline Step & Variable & $R$ & $R^{2}$ & Adjusted $R^{2}$ & Standardised $\beta$ & $p$ \\
\hline 1 & Attitude of acceptance & .75 & .56 & .55 & 0.75 & .029 \\
\hline
\end{tabular}


behaviour of the individual, by emphasising current or former good deeds or even weakness.

Considering the model of risk factors of the sentimentality style, there is a significant role of only one variable, characteristic for mothers of minors, namely the attitude of rejection. This model explains quite a significant percentage of sentimentality differentiation - as much as $56 \%$. It can be concluded that the development of sentimentality is enhanced by mothers, not providing emotional warmth, avoiding their own children, being hostile to them and not showing interest in their affairs. Minors develop, as a result, cognitive defensive strategies against the "self".

Minors, experiencing little sensitivity, lack of support, being rejected in their childhood, develop a cognitive representation of reality in the category of soliciting social acceptance, by reference to the "higher goals", simultaneously breaking norms. More than $40 \%$ of variation in sentimentality is explained by other predictors that are not taken into account in this research, and that certainly would complete the quality of the risk factors model.

\section{CUT-OFF}

Cut-off, as a criminal thinking style, is characterised by a tendency to isolate oneself from liability, and impulsivity in action. The stepwise regression analysis revealed the existence of two cut-off risk factors. The strongest predictor is an attitude of rejection adopted by the mothers. In the next step (Step 2), there entered into the equation an independent variable, the demanding attitude. The results are shown in Table 3. As can be seen, the model explains $38 \%$ of the variability of the test variable of cut-off $\left(R^{2}=.39\right)$.

The risk of cut-off is greater, the more rejecting and challenging is the educational attitude preferred by the mothers of minors. The specificity of the parent-child relationship plays an important role in shaping the distortion. This means that the application of such a strategy is largely the result of environmental conditions - in a range of the expression of the mother's attitudes to minors. This shows that juveniles who activate cognitive distortion of a cutoff are being brought up in a family environment characterised by a negative and hostile attitude of a parent to a child, strong control over his behaviour, rigor and punitiveness (cf. Borecka-Biernat, 2001).
The adoption by mothers of the attitude based on a relationship involving dominance of the parent and deference of the child develops tendencies to categorise reality according to a divalent criterion in minors (cf. Farrington, 1995; Jakubik, 1997). The parent accepts and supports the child's behaviour that is consistent with his or her beliefs (cf. Plopa, 2008). He or she does not tolerate discrepancies between the results of the child's behaviour and their expectations. Even the smallest derogations are treated as failing to meet obligations, and the parent blames the child. $\mathrm{He}$ or she does not take into account the reasons for these discrepancies. Even the lack or insufficient amount of capability of the child is not an excuse. These educational conditions result in a lack of the child's sense of security. Referring to the leading representatives of Bowlby's attachment theory (Bowlby, 2007), Ainsworth (1979) or Crittenden (2002, 2006), the conditions of education are an extremely important context for the development of a type of attachment; in turn, it determines the direction of stimuli (information) perception coming from the outside and inside. Raising a child in the described conditions develops an orientation towards what is planned. The obtained research results indicate that mothers who exhibit little sensitivity, do not support their children, do not protect against negative experiences and establish high standards, develop in the child a sense of uncertainty and the need to achieve his or her goals in line with the expectations of the parent. In turn, emotional coldness, avoidant and limiting contact with the child tendencies, as well as attitudes of rejection, trigger defensive reactions of a lack of emotional control (cf. Borecka-Biernat, 2005).

\section{ENTITLEMENT}

The forward stepwise regression analysis allowed, in the fifth step, to reduce the number of variables relevant to the cognitive distortion of entitlement to five variables, namely: self-esteem index - the identity, criminal thinking pattern of mothers - entitlement, attitude of acceptance-rejection, preferred values of the third focus, and the self-esteem diversity index. The details of the regression analysis are presented in Table 4.

The variables introduced in the fifth step explain about $71 \%$ of entitlement's variance. The results of

Table 3

Cut-Off Risk Factors Model

\begin{tabular}{ccccccc}
\hline Step & Predictor & $R$ & $R^{2}$ & Adjusted $R^{2}$ & Standardised $\beta$ & $p$ \\
\hline 1 & Attitude of rejection & .43 & .34 & .33 & 0.39 & .012 \\
2 & Demanding attitude & .48 & .39 & .39 & 0.33 & .010 \\
\hline
\end{tabular}


Table 4

Entitlement Risk Factors Model

\begin{tabular}{ccccccc}
\hline Step & & $R$ & $R^{2}$ & Adjusted $R^{2}$ & Standardised $\beta$ & $p$ \\
\hline 1 & Self-esteem: identity & .68 & .46 & .43 & 0.41 & .001 \\
2 & Thinking style of mothers: entitlement & .76 & .57 & .54 & 0.46 & .009 \\
3 & Attitude of acceptance-rejection & .79 & .62 & .59 & -0.57 & .012 \\
4 & Focus of values 3 & .81 & .66 & .62 & 0.52 & .021 \\
5 & Self-esteem: diversity index & .84 & .71 & .67 & 0.27 & .032 \\
\hline
\end{tabular}

the logistic regression indicate that the strongest predictor of entitlement is the attitude of rejection $(\beta=-0.57)$. Equally important is the preferred value system of mothers $(\beta=0.52)$. Further variables affecting entitlement are the thinking style of mothers (entitlement) $(\beta=0.46)$ and the identity of minors $(\beta=0.41)$. The last risk factor in order is an indicator of the inconsistency of self-esteem in different areas of knowledge about oneself $(\beta=0.27)$. Regression analysis shows that if mothers of minors, within the emotional and behavioural contact, reject their charges, there is an increase in the risk of developing entitlement mental strategies. In addition, the preference of values such as happiness, prosperous life and social recognition means that thinking and acting of mothers is self-oriented. It is evident that the less favourable, less warm, not accepting attitudes of mothers to the child increase the risk of developing the cognitive distortion. The child, participating in the interaction with the mother, evaluates (interprets) the consequences of behaviour resulting from this relationship. In such educational circumstances, the assessment processes are experienced by the child in the category of "painful - unpopular - wrong" (cf. Bowlby, 2007). Emotional contact disorders in the family contribute to the experiencing of frustration of psychogenic needs by the child (cf. Borecka-Biernat, 1992; Barriga, Hawkins, \& Camelia, 2008; Capaldi, Pears, Patterson, \& Owen, 2008; Goodman, 2002). Such emotional deficits are favourable circumstances for the child to feel hostility and aggression. If the assessment processes are felt strongly, i.e. "the more vividly the consequences of a behaviour are experienced as (...) painful, the faster and more durable (...) will be the resulting learning" (Bowlby, 2007, p. 143).
The results of the regression analysis confirm ( $\beta=0.41)$ that self-esteem is an important factor in determining the existence of the entitlement thinking style. Gold and Mann (1972, as in: Kubacka-Jasiecka, 2006, p. 89) propound functioning, in adolescents involved in criminal activities, a stratified self-esteem and the concept of "self". Using the suggestions of Winnicot (1965, as in: Gasiul, 2001, p. 47), implying the existence of the "true" and "false" "SELF" due to improper family experiences, it can be assumed that the style of thinking - entitlement is a consequence or symptom of a large discrepancy between the two images. Some instability of the "SELF" concept is the result of conditions that shape the concept of "self". It is the result of copied assessments of others. This leads to the relative instability of the "self" concept. The image of "self" depends on the perception of the importance of interpersonal situations and the role of the entity in it. This contributes to a constant modification and development of the self-image. The mere existence of different styles of criminal thinking criminal of the instability of "self". The consequence is a lack of maturity and identity. The criminal thinking styles are to some extent a sign of immaturity of people. These characteristics reinforce efforts of "self" to strengthen and confirm the self-image in relation to the external environment (cf. Kubacka-Jasiecka, 2006).

\section{SUPEROPTIMISM}

The risk factors of superoptimism, as another criminal thinking style, are three independent variables: an inconsistent parental attitude, the value system of mothers (focus 1), and a sense of control in the event of failure. The analysis results are shown below (Table 5).

Table 5

Superoptimism Risk Factors Model

\begin{tabular}{ccccccc}
\hline Step & Predictor & $R$ & $R^{2}$ & Adjusted $R^{2}$ & Standardised $\beta$ & $p$ \\
\hline 1 & Parental attitude: inconsistent & .46 & .34 & .34 & 0.39 & .009 \\
2 & LOC_fail & .48 & .37 & .36 & -0.24 & .012 \\
3 & Value system 1 & .49 & .40 & .38 & -0.19 & .025 \\
\hline
\end{tabular}


Table 6

Discontinuity Risk Factors Model

\begin{tabular}{ccccccc}
\hline Step & Predictor & $R$ & $R^{2}$ & Adjusted $R^{2}$ & Standardised $\beta$ & $p$ \\
\hline 1 & Parental attitude: inconsistent & .56 & .31 & .24 & 0.29 & $<.001$ \\
2 & Sense of control fail & .70 & .49 & .45 & -0.55 & .012 \\
3 & Self-esteem: global & .77 & .59 & .54 & -0.45 & .042 \\
\hline
\end{tabular}

The best predictor of superoptimism is an inconsistent parental attitude $(\beta=0.39)$. At the same time, it turned out that this style is negatively correlated with a sense of control in the event of failure $(\beta=-0.24)$, and the value system of focus 1 preferred by mothers $(\beta=-0.19)$. The risk factors model reduced to three independent variables explains $39 \%$ of the variability of results in the analysed criminal thinking pattern.

The attitude of inconsistency as the strongest risk factor of this style is one of the attitudes undoubtedly disrupting the functioning of the family environment (cf. Ambert, 1997). Given the specificity of the declared parental attitude of mothers, it can be assumed that the child is not able to develop a deep and secure bond with the mother. The calculations indicate that in the case of mothers who have volatile feelings and behaviour toward the child, the child creates an unstable picture of the world. The child is exposed to ineffective parenting practices, such as instability of discipline and affection, in conditions which, to a significant extent, involve the risk of anti-social functioning (cf. Patterson, 1992; Loeber \& Farrington, 1998). The regression analysis does not allow one to determine how the attitude shapes a specific way of psychosocial functioning of the child through which the superoptimism is being created. On the other hand, it is not possible to indicate to what extent learning the maternal behavioural pattern, which manifests itself in the attitude of inconsistency, is the predictor of superoptimism. When considering the impact of the value system of the hedonistic and self-realisation-oriented mothers on the pattern of thinking, it can be concluded that the child learns rather a pattern of the mother's behaviour, which is then visible in an individual's content of thinking.

The importance of parental attitudes and value system for superoptimism can be explained by referring to the theory of social information processing (cf. Crick \& Dodge, 1989, 1994, 1996; Dodge, 2002). It highlights the role of the "pre-existing schemata" and cognitive activity of parents in defining (conditioning) the quality of the relationship with the child. According to the assumptions of the theory, the child's psychosocial functioning is dependent on the preferred values and formed beliefs of parents, which constitute the content of these schemes. It is worth noting that the parental attitude is a result of global attitudes towards all children and attitudes de- pending on the context, that is, attitudes that relate to one's own child. This second type of behaviour is moderated by situational factors, such as the behaviour of the child or the level of a stressful situation (Milner, 2003).

The last risk factor of superoptimism is an external sense of control in the event of failure. This means that a person, regardless of the perception of whether the situation is and exercise or has a purpose, views the situation of failure in terms of a sense of being not guilty and blaming external factors.

\section{DISCONTINUITY}

The forward stepwise regression analysis allowed, in the third step, the number of variables relevant to cognitive distortions of the nature of discontinuity to be reduced to three variables, namely: the global self-esteem, sense of locus of control and inconsistent parental attitude. Table 6 presents the results of the regression analysis.

The three-variable regression model explains about $59 \%$ of the variance in the thinking style - discontinuity. The strongest predictor is a sense of control. It is shown by the standardized beta coefficient $\beta=-0.55$. In the second place, in terms of the influence on the formation of the dependent variable, there is self-esteem. The value of the standardized beta for this variable is $\beta=-0.45$. The weakest predictor of discontinuity of action is the inconsistent parental attitude of mothers. The standardized beta for this variable is $\beta=0.29$.

The obtained results highlight the role of sense of locus of control, in maintaining discontinuity. It must therefore be concluded that the analysed way of thinking is largely a result of forming a specific style of attribution, which determines the generalized expectations of the causal relationships between one's own behaviour and its consequences.

Referring to the research proposals of Hersch and Scheibe (1967), it should be noted that external sense of locus of control is largely correlated with overall self-esteem, and so the existence of an interdependent influence of these variables on the formation of discontinuity can be assumed. The self-esteem being, as well as a sense of control, the domain of the Cognitive Network, determines the perception of self, or 
self-image. The value of the standardized $\beta$ of the predictor is -0.55 , which means that the discontinuity of action increases with the lowering of self-esteem.

The third predictor of discontinuity of action, at the same time having the lowest impact on the dependent variable, is the attitude of inconsistency of fathers. As has been mentioned repeatedly, the declared parental attitude plays an extremely important role in the psychosocial development of an individual. Lack of consistency for a child can result in a lack of emotional constancy and a sense of emotional instability (cf. Urban, 2000; Barber, Olsen, \& Shagel, 1994). Inconsistency and instability of impacts and the lack of involvement of the father in a child's life can be the foundation for development of low and divergent self-esteem and the external sense of locus of control.

\section{COGNITIVE INDOLENCE}

Based on the value of the coefficient of determination, $R^{2}$, it can be concluded that the variables entered in the second step explain about $60 \%$ of the variance of cognitive indolence. The coefficient of determination is high, indicating that the abstracted independent variables substantially control the variation of cognitive indolence. The details of the regression analysis are presented in Table 7 .

Based on the results of the logistic regression, it is noted that the strongest predictor of cognitive indolence is an external sense of locus of control $(\beta=-0.55)$. The second risk factor of this cognitive distortion is the adopted parental attitude of mothers, namely the protective attitude $(\beta=0.44)$.

The results of the regression analysis show the importance of the relationship which had developed between the mother and child for the emergence of cognitive indolence. As indicated by the results of the regression analysis, the parental attitude of the mother prevents the development, in the child, of a sense of autonomy, decisiveness and awareness of self-efficacy. The mother, seeing her child as a dependent individual, has a sense of responsibility for him or her, and thus does not allow the child to develop a sense of responsibility for himself or herself by actively exploring the environment and formulating a catalogue of possible behaviours or coping strategies. The degree of acceptance of the child by the mother is large, but the severity of the control over the child is also significant. The child, being under the influence of such an educational process, learns that it is not necessary to have a sense of responsibility for himself or herself. As a result, the child shapes the representation of reality largely based on the templates provided by his or her mother (cf. Hoffman, 2000). Based on the approach of Hoffman (2000), parents use some kind of "inductions" and parental messages through which the child shapes the image of the environment. The mother, adopting the protective attitude towards the child, develops in him or her a lack of initiative and a low degree of perseverance and originality in solving problems or achieving goals. The child does not learn independent gaining of knowledge, problem solving or meeting his or her own needs. The child does not develop the skills of perception of reality from many perspectives, of searching for new solutions. The consequence of this relationship is rigidity of thinking and acting.

The result of the regression analysis shows that when the juvenile manifests a sense of outer containment, he or she is also characterized by higher severity of cognitive indolence in thinking. The tendency to cognitive passivity, or a certain automatism and rigidity in thinking and action, is determined by a sense of lack of control over the results of the action.

\section{POWER ORIENTATION}

The risk factors model for this thinking pattern explains about $60 \%$ of the variance of the cognitive distortion. The comparison of standardised values shows that the impact of variables included in the model is varied. The results of the regression analysis are presented in Table 8.

The results of the statistical calculations show that the strongest predictor for power orientation is the indicator of empathy - perspective-taking $(\beta=-0.69)$, then the global self-esteem $(\beta=-0.33)$ and demanding parental attitude $(\beta=0.29)$. Taking into account the direction of the impact of the variable of empathy, it can be said that the risk of developing power orientation is greater the lower is the ability of the juvenile to spontaneously recognise and understand his or her own and others' emotions. It can be argued that deficits in empathising with a psychological position of a person increase the risk of power-oriented thinking. Another risk factor of power orientation is self-esteem. The standardized $\beta$ coefficient suggests that the risk of disclosure of power orientation oc-

Table 7

Cognitive Indolence Risk Factors Model

\begin{tabular}{ccccccc}
\hline Step & Predictor & $R$ & $R^{2}$ & Adjusted $R^{2}$ & Standardised $\beta$ & $p$ \\
\hline 1 & LOC: global & .66 & .54 & .53 & -0.55 & .013 \\
2 & Parental attitude: protecting & .69 & .60 & .59 & 0.44 & .025 \\
\hline
\end{tabular}


Table 8

Power Orientation Risk Factors Model

\begin{tabular}{ccccccc}
\hline Step & Predictor & $R$ & $R^{2}$ & Adjusted $R^{2}$ & Standardised $\beta$ & $p$ \\
\hline 1 & Empathy: taking the perspective & .71 & .50 & .49 & -0.69 & .009 \\
2 & Global self-esteem & .75 & .57 & .55 & -0.33 & .025 \\
3 & Parental attitude: demanding & .78 & .61 & .58 & 0.29 & .032 \\
\hline
\end{tabular}

curs when the minor has a low global self-esteem $(\beta=-0.33)$. This means that a person in almost every area of activity sees himself or herself in an adverse, worse light. The risk is greater when the mother places excessive demands on the child; the parent of such an educational style looks at the baby through the prism of the degree of fulfilled responsibilities or acquired success. In this way, the child clarifies his or her self-image as a person who, seeking to be accepted, must show his or her effectiveness and strength.

\section{CONCLUSIONS}

The factors of criminal thinking styles identified by the regression analysis show the complexity and heterogeneity of factors contributing to the emergence of these cognitive distortions. The predictors include both properties conditioning psychosocial functioning of mothers and factors determining the personality of the minor. There is a noticeable advantage of factors attributable to the mothers - variables derived from the environment. Nevertheless, the results of these findings may be inaccurate. It should be noted that no account was taken of the existence of the relationship between independent variables, and therefore the importance of the impact of the mothers' traits on the personality characteristics of minors was not analysed. The consequence of this is already apparent in the fact that there were fewer personality variables for cognitive patterns. The indisputable conclusion is the role of the social environment in the emergence of cognitive distortions. An often appearing predictor of cognitive distortions is the adopted parental attitude. The obtained research results showed only the importance of the attitude as a global trait. It would be valuable to determine which of the components of the attitude implies a specific effect - the behaviour (cf. Barber, 1996; Darling \& Steinberg, 1993; Lewis \& Brooks-Gunn, 1981; Mize \& Pettit, 1997).

Speaking of predictors of criminal thinking styles, it can be summarised that the group of risk factors consists of different variables of mothers and minors. An important conclusion of this research is the fact that educational practices contributing to the development of behavioural and emotional problems of the child are largely the result of experiencing difficult situations and stress of everyday life. This means that the behaviour of a parent is a kind of intermediate link between the difficult circumstances of life suffered by the parent and problems of the child (cf. Magnusom \& Waldfogel, 2005; Deater-Deckard \& Dodge, 1997; Deater-Deckard, 2005).

Funding sources: MNiSW N N110 186637 grant.

\section{References}

Ainsworth, M. S. (1979). Infant-mother attachment. American Psychologist, 34, 932-937.

Ambert, A. M. (1997). Parents, Children, and Adolescent: Interactive Relationship and Development in Context. New York: The Haworth Press.

Appleyard, K., Egeland, B., van Dulmen, M. H. M., \& Sroufe, L. A. (2005). When more is not better: The role of cumulative risk in child behavior outcomes. Journal of Child Psychology and Psychiatry, 46, 235-245.

Aunola, K., Stattin, H., \& Nurmi, J. E. (2000). Adolescents' achievement strategies, school adjustment, and externalizing and internalizing problem behaviors. Journal of Youth and Adolescence, 29, 289-306.

Barber, B. K. (1996). Parental psychological control: Revisiting a neglected construct. Child Development, 67, 3296-3319.

Barber, B. K., Olsen, J. E., \& Shagel, S. C. (1994). Associations between Parental Psychological and Behavioral Control and Youth Internalized and Externalized Behaviors. Child Development, 65, 1120-1136.

Barriga, A. Q., Hawkins, M. A., \& Camelia, C. R. T. (2008). Specificity of cognitive distortions to antisocial behaviours. Criminal Behaviour and Mental Health, 18, 104-116.

Błachut, J., Gaberle, A., \& Krajewski, K. (2006). Kryminologia [Criminology]. Gdańsk: Arche.

Baldwin, M. W. (1992). Relational schemas and the processing of social information. Psychological Bulletin, 112, 461-484.

Borecka-Biernat, D. (1992). Styl wychowania w rodzinie a agresywne zachowanie dzieci [Upbringing styles in the family vs aggressive children behaviour]. Acta Uniwersitatis Wratislaviensis, No 1215. Prace Psychologiczne, XXVI, 125-141.

Borecka-Biernat, D. (2001). Rodzinne predykatory agresji fizycznej młodzieży w sytuacjach społec- 
znie trudnych [Family predictors youth physical aggression in socially difficult situations. Deviations among youth. Conditioning and prevention]. In: B. Urban (ed.), Dewiacje wśród mtodzieży. Uwarunkowania i profilaktyka [Deviations among youth. Conditioning and prevention]. Kraków: PWN.

Borecka-Biernat, D. (2005). Percepcja postaw rodzicielskich a emocjonalno-obronne strategie radzenia sobie młodzieży w sytuacji trudnej [Parental attitude perception vs. emotional-defending strategies in youth coping with difficult situation]. In: T. Sołtysiak (ed.), Zagrożenia w wychowaniu I socjalizacji mtodzieży oraz możliwości ich przezwyciężenia [Risks in the upbringing and socialization of youths and the possibility of them overcoming]. Bydgoszcz: PWN.

Bowlby, J. (2007). Przywiązanie [Attachment]. Warszawa: PWN.

Brzozowski, P. (1989). Skala wartości (SW). Polska adaptacja Value Survey M. Rokeacha [Value Survey. Polish adaptation]. Warszawa: PTP.

Brzozowski, P. (1996). Skala Wartości (SW). Polska adaptacja Value Survey M. Rokeacha. Podręcznik [Value Survey. Polish adaptation]. Warszawa: PTP.

Capaldi, D. M., Pears, K. C., Patterson, G. R., \& Owen, L. D. (2003). Continuity of parenting practices across generations in an at-risk sample: a prospective comparison of direct and mediated associations. Journal of Abnormal Child Psychology, 31, 127-142.

Capaldi, D. M., Pears, K. C., Kerr, D. R., \& Owen, L. D. (2008). Intergenerational and partner influence on fatheres' negative discipline. Journal Abnormal Child Psychology, 36, 347-358.

Crick, N. R., \& Dodge, K. A. (1989). Children's perceptions of peer entry and conflict situations: social strategies, goals, and outcome expectations. In: B. Schneider, J. Nadel, G. Attili, \& R. Weissberg (eds.), Social competence in developmental perspective. Boston, MA: Kluwer Academic Publishers.

Crick, N. R., \& Dodge, K. A. (1994). A review and reformulation of social information-processing mechanisms in children's social adjustment. Psychological Bulletin, 115, 74-101.

Crick, N. R., \& Dodge, K. A. (1996). Social information-processing mechanisms on reactive and proactive aggression. Personality and Social Psychology Bulletin, 67, 993-1002.

Crittenden, P. M. (2002). Attachment, information processing, and psychiatric disorder. World Psychiatry, 1, 72-75.

Crittenden, P. M. (2006). A Dynamic-Maturational Model of Attachment. Australien \& New Zealand Journal of Family Therapy, 27, 105-115.

Darling, N., \& Steinberg, L. (1993). Parenting style as context: An integrative model. Psychological Bulletin, 113, 487-496.
Davis, M. H. (1999). Empatia. O umiejętności wspótodczuwania [Empathy. On compassion ability]. Gdańsk: Gdańskie Wydawnictwo Psychologiczne.

Deater-Deckard, K., \& Dodge, K. A. (1997). Externalising behavior problems and discipline revisited: nonlinear effects and variation by culture, context and gender. Psychological Inquiry, 8, 161-175.

Deater-Deckard, K. (2005). Parenting stress and children's development: introduction to the special issue. Infant and Child Development, 14, 111-115.

Dodge, K. A. (1991). The structure and function of reactive and reactive aggression. In: D. J. Pepler, \& K. H. Rubin (eds.), The development and treatment of childhood aggression (pp. 201-218). Hillsdale, NJ: Lawrence Erlbaum.

Dodge, K. A., \& Tomlin, A. M. (1987). Utilization of self-schemas as a mechanism of interpersonal bias in aggressive children. Social Cognition, 5, 280-300.

Dodge, K. A., \& Somberg, D. R. (1987). Hostile attributional biases among aggressive boys are exacerbated under conditions of threats to the self. Child Development, 58, 213-224.

Dodge, K. A., \& Coie, J. D. (1987). Social-information-processing factors in reactive and proactive aggression in children's peer groups. Journal of Personality and Social Psychology, 53, 1146-1158.

Dodge, K., Price, J., Bachorowski, J., \& Newman, J. (1990). Hostile Attributional Biases in Severely Aggressive Adolescents. Journal of Abnormal Psychology, 99, 385-392.

Dodge, K. A. (2002). Mediation, moderation, and mechanisms in how parenting affects children's aggressive behavior. In: J. G. Borkowski, S. L. Ramey, \& M. Bristol-Power (eds.), Parenting and the child's world: Influences on academic, intellectual, and social-emotional development (pp. 215-229). Mahwah, NJ: Erlbaum.

Farrington, D. P. (1994). Childhood, adolescent, and adult features of violent males. In: L. R. Huesmann (ed.), Aggressive Behavior: Current Perspectives. New York: Plenum.

Farrington, D. P. (1995). The development of offending and antisocial behavior from childhood: Key findings from the Cambridge study in delinquent development. Journal of Child Psychology and Psychiatry, 36, 929-964.

Farrington, D. P., Coid, J., \& Murray, J. (2009). Family factors in the intergenerational transmission of offending. Criminal Behavior and Mental Health, 19, 109-124.

Ferguson, G. A., \& Takane, Y. (2003). Analiza statystyczna w psychologii i pedagogice [Statistical analysis in psychology and pedagogics]. Warszawa: Wydawnictwo Naukowe PWN.

Fitts, W. H. (1975). Podręcznik do skali badania obrazu wtasnej osoby (skala samooceny) [Handbook for self-esteem scale]. Warszawa. 
Gasiul, H. (2001). W poszukiwaniu podstaw rozwoju ja emocjonalnego (In search of basis of emotional development). Warszawa: Wyd. Akademickie Żak.

Goodman, S. (2002). The Parental Discipline-Child Behavior Problems Puzzle: Some New Pieces.

Gorman-Smith, D., \& Tolan, P. H (1998). The role of exposure to community violence and developmental problems among inner-city youth. Development \& Psychopathology, 10, 101-116.

Gorman-Smith, D., Tolan, P. H., Loeber, R., \& Henry, D. (1998). The relation of family problems to patterns of delinquent involvement among urban youth. Journal of Abnormal Child Psychology, 26, 319-333.

Hart, C. H., De Wolf, M. D., Wozniak, P., \& Burts, D. C. (1992). Maternal and Paternal Disciplinary Styles: Relations with Preschoolers' Playground Behavioral Orientations and Peer Status. Child Development, 63, 879-892.

Hart, C. H., Olsen, S. F., Robinson, C. C., \& Mandleco, B. L. (1997). The development of social and communicative competence in childhood: Review and a model of personal, familial, extrafamilial processes. Communication Yearbook, Vol. 20. New York: Sage Publications.

Hersch, P. D., \& Scheibe, K. E. (1967). Reliability and validity of internal-external control as personality dimensions. Journal of Consulting Psychology, 31, 609-613.

Hoffman, M. L. (2000). Empathy and moral development: Implications for caring and justice. New York: Cambridge University Press.

Holman, J. E., \& Quinn, J. F. (1992). Criminology: Applying theory. ST. Paul: West Publishing Company.

Huesmann, L. R. (2005). Mechanisms and theories of cross-generational transmission of aggression. Acta Neurobiologiae Experimentalis, 65, 236.

Jakubik, A. (1997). Zaburzenia osobowości [Personality disorders]. Warszawa: PZWL.

Krasowicz, G., \& Kurzyp-Wojnarska, A. (1990). Kwestionariusz do badania poczucia kontroli (KBPK) [Questionnaire for sense of control]. Warszawa: Polskie Towarzystwo Psychologiczne.

Kubacka-Jasiecka, D. (2006). Agresja i autodestrukcja z perspektywy obronno-adaptacyjnych dażeń JA [Aggression and autodestruction from defensive-adaptative pursuance perspective]. Kraków: Wydawnictwo Uniwersytetu Jagiellońskiego.

Lewis, M., \& Brooks-Gunn, J. (1981). Infant social perception: Responses to pictures of parents and strangers. Developmental Psychology, 17, 647-649.

Loeber, R., \& Farrington, D. P. (1998). Serious and violent juvenile offenders: Risk factors and successful interventions. Thousand Oaks, CA: Sage.

Magnuson, K., \& Waldfogel, J. (2005). Early childhood care and education, and ethnic and racial test score gaps at school entry. The Future of Children, 15, 169-196.
Maruna, S., \& Mann, R. (2006). A fundamental attribution error? Rethinking cognitive distortions. Legal and Criminological Psychology, 11, 155-177.

McClun, L. A., \& Merrell, K. W. (1998). Relationship of perceived parenting styles, locus of control orientation, and self-concept among junior high age students. Psychology in the Schools, 35, 381-390.

Midgley, C., Arunkumar, R., \& Urdan, T. (1996). "If I don't do well tomorrow, there's a reason": Predictors of adolescents' use of academic self-handicapping strategies. Journal of Educational Psychology, 88, 423-434.

Milner, J. S. (2003). Social information processing in high-risk and physically abusive parents. Child Abuse \& Neglect, 27, 7-20.

Mize, J., \& Pettit, G. S. (1997). Mothers' social coaching, mother - child relationship style, and children's peern competence: Is the medium the message? Child Development, 68, 312-332.

Obuchowski, K. (1970). Kody orientacji i struktura procesów emocjonalnych [Orientation codes and structure of emotional processes]. Warszawa: PWN.

Patterson, G. R. (1992). Developmental changes in antisocial behavior. In: R. D. Peters, R. J. McMahon, V. L. Quinsey (eds.), Aggression and violence throughout the life span (pp. 52-82). Newbury Park, Ca: Sage.

Plopa, M. (2008). Skala Postaw Rodzicielskich. Wersja dla rodziców [Parental Attitude Scale. Version for parents]. Warszawa: WSFiZ Pracownia Testów Psychologicznych.

Rode, M., \& Rode, D. (2011). Criminal Thinking Styles of Juvenile Delinquents. Problems of Forensic Science, 84, 356-379.

Rode, M. (2013). Style myślenia przestępczego. Podstawy teoretyczne i diagnostyczne [Criminal thinking styles. Theoretical and diagnostic basis]. Warszawa: Difin.

Roese, N. J., \& Olson, J. M. (2007). Better, Stronger, Faster. Self-Serving Judgment, Affect Regulation, and the Optimal Vigilance Hypothesis. Perspectives on Psychological Science, 2, 124-141.

Siemaszko, A. (1993). Granice tolerancji. O teoriach zachowań dewiacyjnych [Tolerance borders. On deviated behaviours thories]. Warszawa: PWN.

Stanik, J. M. (1980). Asocjalność nieletnich przestępców jako przedmiot psychologicznej diagnozy klinicznej [Juvenile delinquency asociality as an subject of clinical psychology diagnosis]. Warszawa: Wydawnictwo Prawnicze.

Steuden, S. (1997). Dynamika zmian osobowości $u$ osób z rozpoznana schizofrenia [Dynamics of personality changes in persons with diagnosed schizophrenia]. Lublin: KUL.

Urban, B. (2000). Zaburzenia w zachowaniu i przestępczość mtodzieży [Conduct disorder and juvenile delinquency]. Kraków: KUL. 
Vermeiren, R., Bogaerts, J., Ruchkin, V., Deboutte, D., \& Schwab-Stone, M. (2004). Subtypes of self-esteem and self-concept in adolescent violent and property offenders. Journal of Child Psychology and Psychiatry, 45, 405-411.

Walters, G. D. (1990). The Criminal Lifestyle. Patterns of Serious Criminal Conduct. Newbury Park - London - New Delhi: Sage Publications.

Walters, G. D. (1995a). The Psychological Inventory of Criminal Thinking Styles: Part I: Reliability and Preliminary Validity. Criminal Justice and Behavior, 22, 307-325.

Walters, G. D. (1995b). The Psychological Inventory of Criminal Thinking Styles: Part II: Identifying Simulated Response Sets. Criminal Justice and Behavior, 22, 437-445.

Walters, G. D., \& White, T. W. (1989). The thinking criminal: A cognitive model of lifestyle criminality. Criminal Justice Research Bulletin, 4, 1-10.

Walters, G. D. (1996). The Psychological Inventory of Criminal Thinking Styles: Part III. Predictive Validity. International Journal of Offender Therapy and Comparative Criminology, 40, 105-112.

Walters, G. D. (1998). The Lifestyle Criminality Screening Form: Psychometric properties and practical utility. Journal of Offender Rehabilitation, 27, 9-23.

Walters, G. D. (2002). The Psychological Inventory of Criminal Thinking Styles (PICTS): A Review and Meta-Analysis. Assessment, 9, 278-291.

Walters, G. D. (2006a). Appraising, researching and conceptualizing criminal thinking: a personal view. Criminal Behaviour and Mental Health, 16, 87-99.

Walters, G. D. (2006b). The Psychological Inventory of Criminal Thinking Styles (PICTS) professional manual. Allentown, PA: Center for Lifestyle Studies.

Walters, G. D. (2006c). Lifestyle Theory: Past, Present and Future. New York: Nova Science Publisher.

Walters, G. D. (2007). The Latent Structure of the Criminal Lifestyle: A Taxometric Analysis of the Lifestyle Criminality Screening Form and Psychological Inventory of Criminal Thinking Styles. Criminal Justice and Behavior, 34, 1623-1637.

Yochelson, S., \& Samenow, S. (1976, 1977). The Criminal Personality (Vol. I, II, III). NY: J. Aronson 